\title{
ANALISIS STABILITAS TEROWONGAN DANGKAL PADA TANAH LUNAK
}

\author{
Putri Nova Haryu Dhanti ${ }^{2)}$ dan Singgih Saptono ${ }^{3)}$ \\ ${ }^{2,3)}$ Program Studi Magister Teknik Pertambangan - Fakultas Teknologi Mineral - \\ Universitas Pembangunan Nasional Veteran Yogyakarta \\ Jalan Pajajaran 104 Condongcatur, Yogyakarta, Indonesia, 55293
}

\begin{abstract}
ABSTRAK
Pada lima tahun terakhir ini banyak pembangunan yang dilakukan di Indonesia khususnya pembangunan infrastruktur, seperti pembangunan sarana Mass Rapid Transportation (MRT) berupa terowongan di Jakarta, dan berapa terowongan jalan raya dan terowongan jalur kereta api. Hal ini menjadi tantangan bagi para pembuatan terowongan di Indonesia. Tantangan tesebut adalah membuat terowongan jalan raya dan kereta api pada tanah lunak khususnya lempung dan pada kedalaman yang dangkal. Hal ini perlu perhatian khusus, disebabkan oleh sifat lempung yang memiliki sifat swelling dan serta penggalian terowongan tersebut pada kedalamanan kurang dari 100 m. Pendekatan kekuatan batuan sudah tidak dapat digolongan sebagai batuan karena pada umumnya menurut meterial lempung digolongkan sebagai tanah, sehingga teori elastistas sudah tidak berlaku lagi. Pendekatan yang diusulkan untuk analisis stabilitas pada terowongan di batuan lempung adalah berperilaku swelling sesuai dengan kandungan mineral penyusunnya yaitu montmorilonit. Untuk itu analisis stabiltas diperlukan parameter swelling. Pada Analisis dengan perilaku sewlling ini menggunakan metode elemen hingga (Phase2, Rocscience). Dengan pendekatan perilaku Swelling dalam analisis stabilitas terwongan akan lebih mendekati dengan sifat material yang ada di terowongan.
\end{abstract}

Kata kunci: swelling, metode elemen hingga, stabilitas, terowongan

\begin{abstract}
In the last five years a lot of development has been carried out in Indonesia, especially infrastructure development, such as the construction of Mass Rapid Transportation (MRT) facilities in the form of tunnels in Jakarta, and how many road tunnels and railroad tunnels. This is a challenge for tunnels in Indonesia. The challenge is to build road and rail tunnels on soft soil, especially clays and at shallow depths. This needs special attention, due to the nature of the clay which has swelling properties and the excavation of the tunnel in the depth of less than $100 \mathrm{~m}$. Rock strength approach can no longer be classified as rock because in general according to clay meterial classified as soil, so the theory of electricity is no longer valid. The proposed approach for the stability analysis of tunnels in clay rock is to behave swelling according to its constituent mineral content, montmorillonite. For this reason, stability analysis requires swelling parameters. In this analysis with sewlling behavior using the finite element method (Phase2, Rocscience). With the Swelling behavior approach in the tunnel stability analysis it will be closer to the material properties in the tunnel.
\end{abstract}

Key words : Swelling, Finite Element Method, Stability, Tunnel 


\section{A. PENDAHULUAN}

Pada penggalian di setiap penambangan selalu berhubungan dengan berbagai material dari material yang sangat lunak (seperti tanah) hingga material batuan yang sangat keras (seperti batuan beku, batuan sedimen dan batuan metamorf). Pada berbagai kasus material yang sangat lunak akan memberikan perilaku khusus seperti berperilaku plastis, dan berperilaku pengembangan (swelling). Pada penelitian ini ada dilakukan suatu studi parameter pada material berperilaku swelling pada material tanah dengan kandungan mineral monmorilonite. Hal ini sangat menarik dikarenakan pada material tanah tersebut mampu mengembang (swelling) sebelum terjadinya keruntuhan, hal ini sangat berbeda pada material plastis. Material plastis akan memiliki sifat plastis sebelum terjadinya pecah (failure). Sehingga pada penelitian ini akan dilihat bagaimana proses perilaku dari hari pertama hingga mencapai hari ke seratus, jika diterapkan pada studi kasus stabilitas terowongan di material berperilaku swelling. Contoh batuan material tanah yang akan dianalis adalah batulempung pada pembawa lapisan batubara, sampel di ambil dari 2 daerah yang berbeda yaitu batu lempung yang berasal dari Kabupaten Kutai Kartanegara, Kalimantan Timur dan Kabupaten Barito Selatan, Kalimantan Tengah. Pengambilan contoh ini didasarkan adanya kasus rencana penambangan batubara bawah tanah dan tambang terbuka.

Dengan adanya mineral lempung pada pembawa lapisan batubara, maka memungkinkan potensi terjadinya swelling. Swelling adalah variasi perubahan kadar air atau peristiwa penyerapan dan pelepasan air oleh mineral lempung yang mengakibatkan perubahan volume. Salah satu dampak swelling pada bukaan tambang bawah tanah dapat menyebabkan lantai tambang mengembang dan lantai menjadi naik, sehinggga dimensi lubang bukaan tambang menjadi lebih kecil daripada rancangan awal dan menyebabkan proses penambangan menjadi terganggu. White (1956) menyatakan bahwa naiknya lantai tambang karena material mengandung lempung terutama mineral montmorillonite.

Pada penelitian ini diperoleh dua karakteristik material berpotensi terjadinya swelling dan material tak berpotensi terjadinya swelling. Kedua material tersebut memiliki karakteristik seperti modulus elastisitas, kohesi, sudut gesek dalam, tensile strength, time swelling parameter, time swelling paramer for elastic strain, time swelling paramete for platic strain, plactic volumetric strain for plastic strain, dan maximum swelling stress - normal serta maximum swelling stress - tangensial. Tujuan penilitian ini akan mencari parameter berpengaruh potensi atau tidak potensinya material terhadap swelling. Selain pada penelitian akan melihat beberapa perilaku yang terjadi pada swelling seperti perilaku elastik, plastik tanpa terjadinya runtuh.

\section{B. METODOLOGI PENELITIAN}

\section{B.1 Geologi Kutai Kartanegara dan Barito Selatan}

Pada penelitian ini, sampel di ambil dari 2 daerah yang berbeda yaitu batulempung di Kabupaten Kutai Kartanegara Kalimantan Timur (Gambar 1), dan di Kabupaten Barito Selatan, Kalimantan Tengah (Gambar 2).

Formasi pembawa batubara di Kabupaten Kutai Kartanegara, Kalimantan Timur adalah formasi Balikpapan. Formasi Balikpapan terdiri dari beberapa siklus endapan delta yang disusun oleh litologi yang terdiri dari perselingan batupasir dan lempung dengan sisipan lanau, serpih, batugamping dan batubara. Batupasir kuarsa, putih kekuningan, tebal lapisan 1-3 m, disisipi lapisan batubara tebal $5-10 \mathrm{~cm}$. Batupasir gampingan, coklat, berstruktur sedimen lapisan bersusun dan silang siur, tebal lapisan $20-40 \mathrm{~cm}$, mengandung foraminifera kecil, disisipi lapisan tipis karbon. Batulempung, kelabu kehitaman, setempat mengandung sisa tumbuhan oksidasi besi yang mengisi rekahan-rekahan setempat mengandung lensa-lensa batupasir gampingan. Lanau gampingan, berlapis tipis.

Formasi pembawa batubara di Kabupaten Barito Selatan, Kalimantan Selatan adalah formasi Tanjung. Formasi Tanjung merupakan batuan Tersier paling tua dan sebagai formasi pembawa 
batubara, dapat dibedakan menjadi dua bagian. Bagian bawah terdiri dari perselingan batu kuarsa dengan lanau bersisipan batugamping dan batubara. Bagian Bawah terdiri dari perselingan batupasir, batulempung dan batulanau. Formasi Tanjung tersingkap di daerah Lemo.

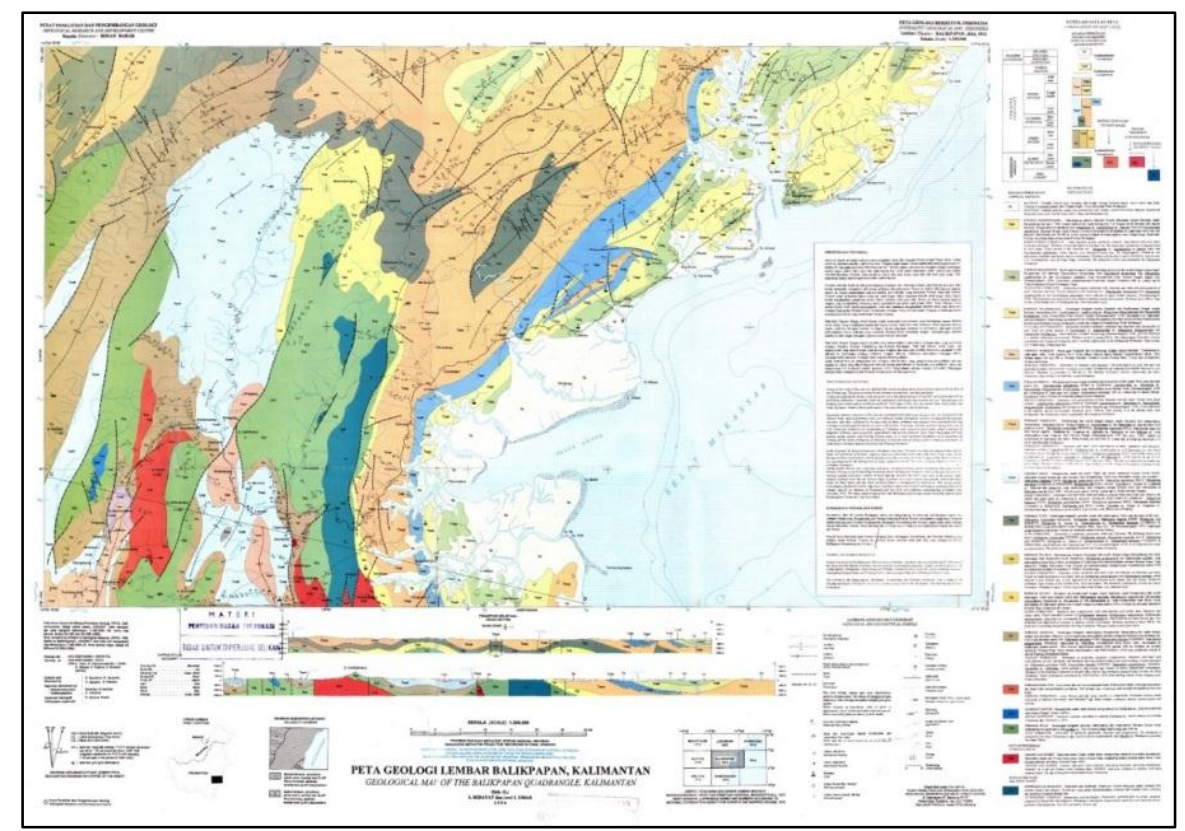

Gambar 1. Kabupaten Kutai Kartanegara (S. Supriatna, dkk 1995)

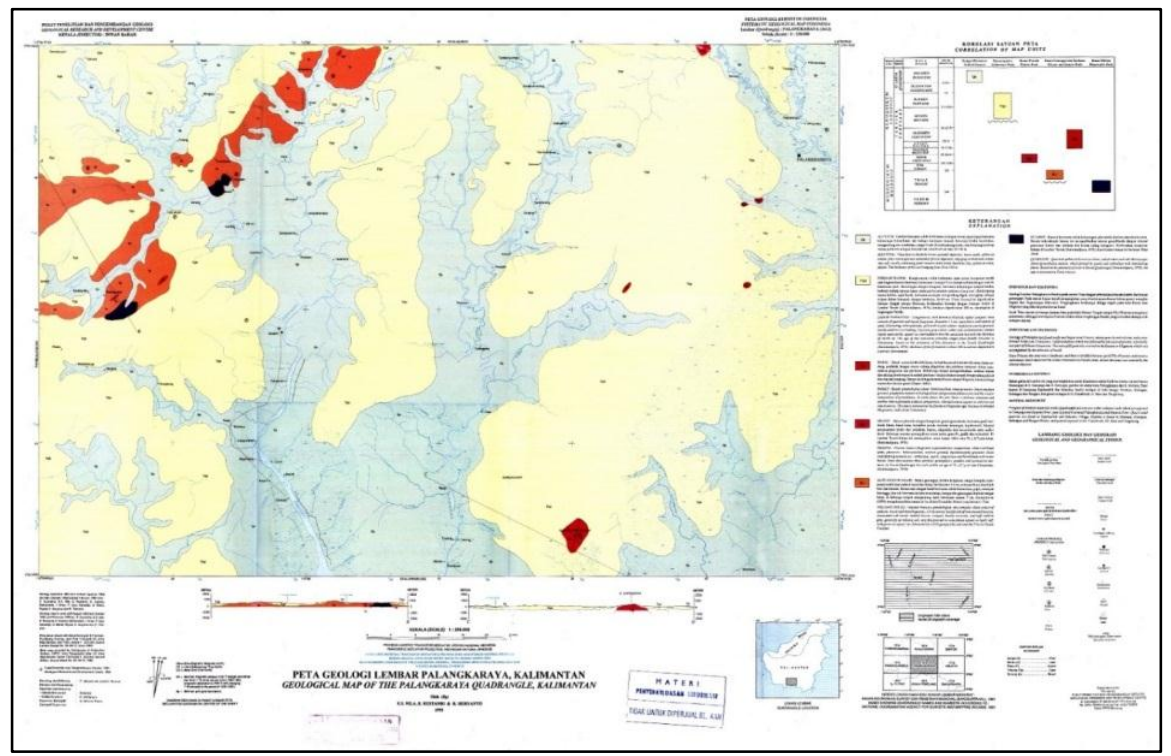

Gambar 2. Kabupaten Barito Selatan (Sikumbang dan Heriyanto, 1994)

\section{B.2 Mineral Lempung}

Di Indonesia dengan pelapukan kimia yang sangat dominan akibat iklim tropis, sehingga banyak menghasilkan berupa batulempung. Salah satu mineral penyusun batuan tersebut adalah mineral lempung yang memiliki sifat mengembang (swelling) dan tidak mengembang.

Mineral lempung, memungkinkan akan terjadinya swelling. Swelling adalah variasi perubahan kadar air yaitu peristiwa penyerapan dan pelepasan air oleh mineral lempung mengakibatkan perubahan volume. Salah satu dampak swelling pada lubang bukaan (terowongan) dapat menyebabkan lantai mengembang dan lantai menjadi naik sehinggga dimensi lubang bukaan menjadi lebih kecil daripada rancangan awal dan menyebabkan stabilitas lubang bukaan menjadi terganggu. 
Pada umumnya sebagian besar wilayah Indonesia ini diliputi oleh lempung dengan pengembangan yang cukup besar (plastisitas tinggi), yaitu akan berubah volumenya (mengembang) bila bertambah (berubah) kadar airnya. Volumenya akan membesar dalam kondisi basah dan akan menyusut bila dalam kondisi kering. Plastisitas adalah keadaan konsistensi, yaitu cair, plastis, semi padat, atau padat bergantung pada kadar airnya. Variasi perubahan kadar air yaitu peristiwa penyerapan dan pelepasan air oleh mineral lempung mengakibatkan perubahan volume atau yang disebut dengan swelling (mengembang atau menyusut dari tanah lempung).Jenis batuan yang paling memperlihatkan perilaku swelling misalnya batulempung dan anhydrite bearing-rock. Walaupun sacara macrocospic perilaku swelling nya tampak sama, namun proses kimia berbeda. Namun swelling tidak hanya bergantung pada sifat-sifat material tetapi juga pada ketersediaan air.

Potensi terjadinya swelling biasanya pada daerah dengan kondisi yang basah atau adanya perubahan kadar air (Pusch, 2012). Swelling terjadi ketika molekul air melekat pada permukaan lempung yang bermuatan negatif. Perubahan molekul air yang sangat terikat pada permukaan lempung untuk air pori bebas secara bertahap terjadi dan memungkinkan terjadinya swelling dengan potensi yang besar. Faktor jarak antar lapisan, ion, valensi, dan ketersediaan air akan berpengaruh pada proses mengalirnya air ke lapisan mineral lempung dan tingkat swelling.

Faktor yang signifikan terhadap peningkatan volume ketika lempung mengalami swelling adalah sementasi mineral lempung gaya tarik menarik anatar partikel lempung dan perekat organik dan anorganik seperti karbonat dan hidroksida (Pusch, 2012). Sementasi partikel melibatkan pembentukan ikatan molekul yang membuat interlayer dalam mineral lempung tidak dapat ditembus oleh kation dan molekul air mampu merusak lempung untuk berekspansi.

\section{B.3 Perilaku Swelling}

Berdasarkan hasil uji swelling setelah Huder dan Amberg (1970), Grob (1972) merumuskan hukum swelling satu dimensi. Hasil uji Huder dan Amberg (1970), digunakan untuk mengukur deformasi luas sebagai akibat dari swelling.

Fenomena naiknya lantai terowongan, atau kerusakan pada invert arch, telah terkenal sejak awal pembangunan terowongan di pertengahan abad ke-19. Fenomena ini telah dikaitkan dengan peningkatan volume massa batuan karena penyerapan air. Batuan yang mengalami swelling mengandung mineral clay, dalam beberapa kasus, bersifat anhidrit. Tinjauan komprehensif dari temuan empiris yang berhubungan dengan penelitian ini diberikan di tempat lain (Anagnostou, 1991). Namun demikian, perlu untuk menyebutkan beberapa fitur dari fenomena yang diamati untuk membedakan swellling dari fenomena lain dalam terowongan, khususnya squeezing.

Berbeda dengan squezing, keberadaan air, serta komposisi mineralogi tertentu sangat berpengaruh untuk terjadinya swelling. Karena squezing (tergantung pada kekuatan batuan dan overburden) pada prinsipnya dapat terjadi pada batuan apa pun, dalam batuan yang mengandung mineral yang menyebabkan swelling juga, kita tidak bisa mengesampingkan kemungkinan terjadinya swelling dan squeezing secara simultan. Namun perlu ditekankan bahwa swelling dan squezing yang simultan adalah fenomena yang agak jarang terjadi yang hanya terjadi pada batuan yang lemah.

Pola khas deformasi yang diamati pada terowongan di batuan yang mengalami swelling terdiri dari, naiknya lantai yang sangat besar dan tidak adanya deformasi yang sebanding di dinding dan crown. Biasanya, batuan yang mengalami swelling menunjukkan plastisitas tinggi selama penggalian. Dinding dan mahkota tetap stabil selama bertahun-tahun. Di laboratorium, seseorang mengukur tekanan swelling yang seringkali lebih tinggi dari tegangan vertikal yang sesuai dengan lapisan penutup di lokasi asli spesimen. Pengamatan in situ jelas menyiratkan bahwa tekanan swelling berbeda dengan jenis tekanan batuan lainnya, bisa lebih tinggi dari tegangan vertikal primer, terutama ketika terowongan dangkal. 


\section{HASIL DAN PEMBAHASAN}

\section{C.1 Hasil Pengujian XRD}

Hasil analisis ini dalam bentuk persentase dari masing-masing jenis mineral yaitu illite, kaolinite, dan monmorillonite, Sebagai pada penelitian ini adalah contoh jenis lempung dari Kutai Kartanegara akan dibandingkan dengan contoh jensi lempung dari Barito Selatan, Hal ini dilakukan untuk mendapatkan perilaku lempung dengan potensi swelling dari contoh tersebut, Potensi perilaku lempung, Selain itu juga dibedakan berdasarkan kemampuan menyerap air, Hasil pengujian ini menunjukan bahwa untuk contoh dari daerah Kutai Kartanegara potensi swellingnya sebesar 19,8\% untuk monmorillonite, sedangkan untuk contoh dari daerah Barito Selatan yang potensi swellingnya kecil menyerap airnya sebesar 2,5\%. Hasil pengujian dengan XRD ini yang berupa Grafik peak contoh dari Kutai Kartanegara (1) dapat dilihat pada Gambar 4 dan peak XRD contoh dari Barito Selatan (1).

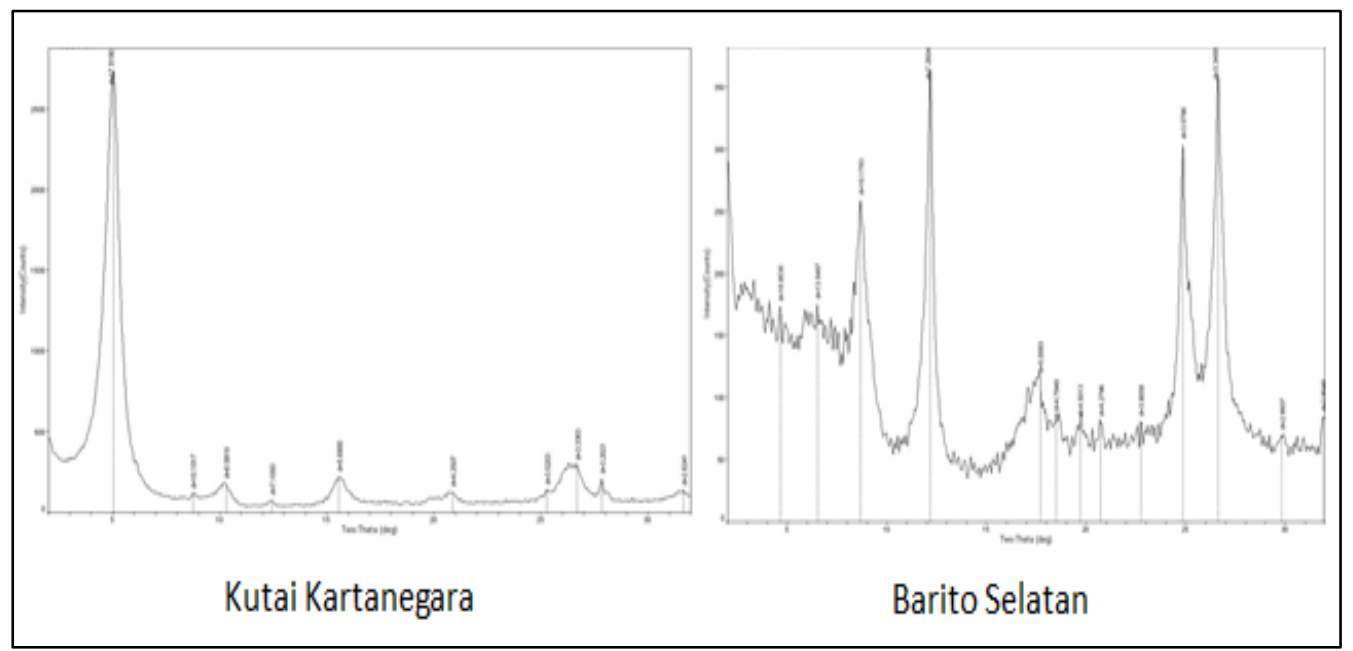

Gambar 4. Grafik peak XRD Kutai Kartanegara \& Barito Selatan

\section{C.2 Hasil Pengujian Swelling}

Uji swelling dilakukan pada cincin besi yang berbentuk silinder (contoh terkekang lateral). Awalnya tanah dibebani dengan tekanan terbagi rata, dan kemudian direndam air. Contoh mengembang secara vertikal dan perubahan tinggi dibagi tinggi awal adalah potensi pengembangannya (dinyatakan dalam persen). Pengujian pengembangan ini dapat dilakukan dengan alat uji oedometer. Lama waktu pengujian dipertimbangkan terhadap waktu yang dibutuhkan untuk masuk ke dalam contoh., karena tanah ekspansif tidak segera mengmbang ketika ditambahkan air.

Berdasarkan Gambar 5. dapat dilihat bahwa daerah Kutai Kartanegara memiliki regangan yang besar terhadap waktu di bandingkan pada Barito Selatan. Hal itu terjadi di karenakan bahwa daerah Kutai Kartanegara memiliki potensi swelling yang besar di banding dengan Barito Selatan. 


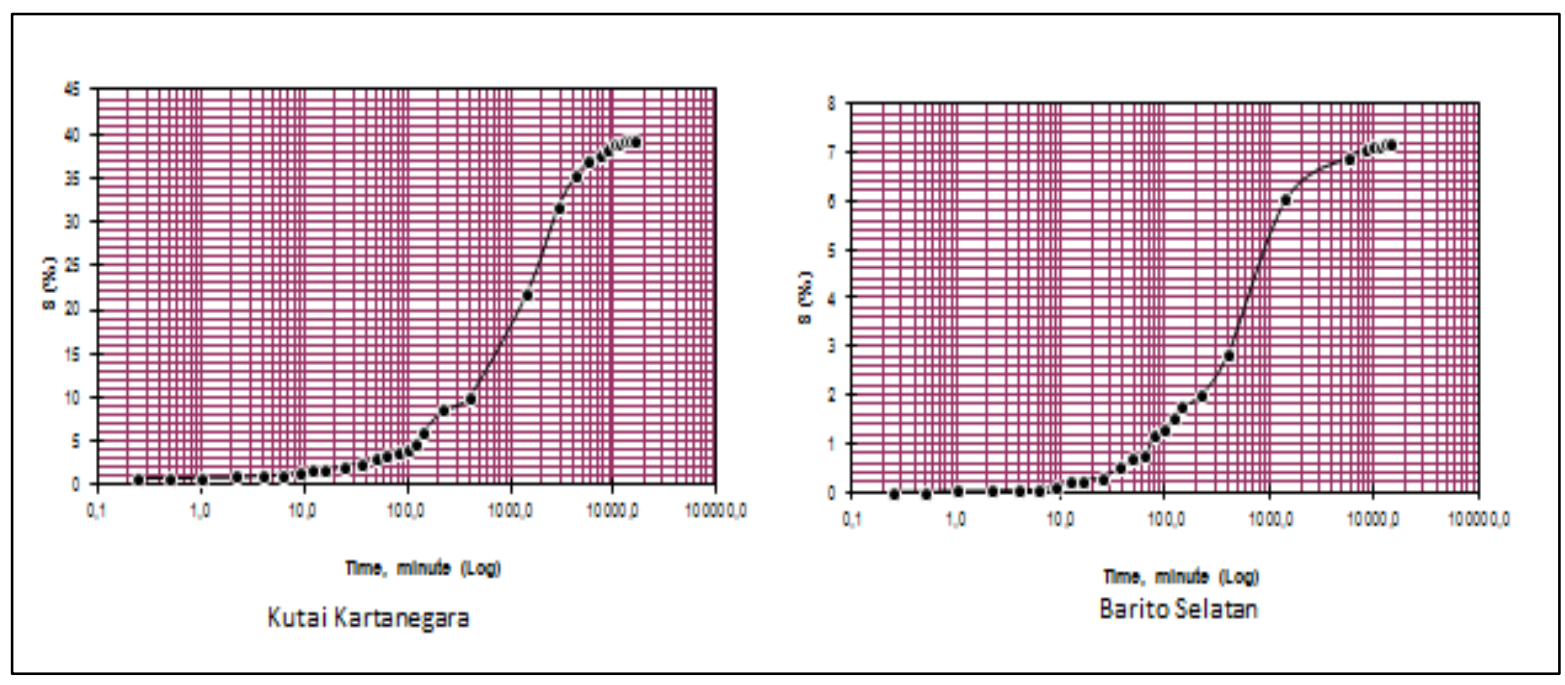

Gambar 5. Grafik hasil pengujian swelling regangan terhadap waktu contoh dari Kutai Kartanegara

\section{C.3 Hasil Analisis Parameter Swelling}

Data input yang diperlukan untuk simulasi di Soil Test Facility (Uji Tanah), dan setelah diolah maka hasil parameter swelling untuk parameter analisis swelling seperti pada Tabel 1 dan Tabel 2, sebagai perbandingan antara potensi swelling dan non swelling.

Tabel 1. Data Material Kutai Kartanegara

\begin{tabular}{cccccc}
\hline Parmeter & Satuan & Nilai & Parameter & Satuan & Nilai \\
\hline$\varphi_{k}$ & $\left({ }^{0}\right)$ & $13-20$ & $\varphi_{k}$ & $\left({ }^{0}\right)$ & $13-20$ \\
$c_{k}$ & $(\mathrm{kPa})$ & $100-180$ & $c_{z}$ & $(\mathrm{kPa})$ & $100-180$ \\
$\psi_{k}, \psi_{s}$ & $\left(^{0}\right)$ & 1 & $v$ & $(-)$ & 0,3 \\
$E$ & $(\mathrm{MPa})$ & $110-190$ & $K_{q, z}$ & $(\%)$ & $31-40$ \\
$K_{q, k}$ & $(\%)$ & $31-40$ & $\sigma_{0}$ & $\mathrm{kPa}$ & $350-550$ \\
\hline
\end{tabular}

Tabel 2. Data Material Barito Selatan

\begin{tabular}{cccccc}
\hline Parmeter & Satuan & Nilai & Parameter & Satuan & Nilai \\
\hline$\varphi_{k}$ & $\left({ }^{0}\right)$ & $20-21$ & $\varphi_{k}$ & $\left({ }^{0}\right)$ & $20-21$ \\
$c_{k}$ & $(\mathrm{kPa})$ & $160-185$ & $c_{z}$ & $(\mathrm{kPa})$ & $160-185$ \\
$\psi_{k}, \psi_{s}$ & $\left(^{0}\right)$ & 1 & $v$ & $(-)$ & 0,3 \\
$E$ & $(\mathrm{MPa})$ & $150-320$ & $K_{q, z}$ & $(\%)$ & $3-8$ \\
$K_{q, k}$ & $(\%)$ & $3-8$ & $\sigma_{0}$ & $\mathrm{kPa}$ & $80-140$ \\
\hline
\end{tabular}

K dan S adalah indeks yang digunakan dalam model Wittke-Gattermann (1998) untuk menunjukkan set sambungan vertikal (tegak lurus terhadap bedding) dan perlapisan horizontal,

Tabel 3 dan Tabel 4 menunjukkan beberapa nilai parameter waktu pembengkakan (swelling time) dalam model Wittke-Gattermann yang digunakan dalam simulasi numerik aplikasi terowongan dengan material penyusun berperilaku plastik dan swelling,

Tabel 3. Parameter waktu pembengkakan (swelling time) Kutai Kartanegara

\begin{tabular}{cccccc}
\hline Parmeter & Satuan & Nilai & Parameter & Satuan & Nilai \\
\hline$A_{0}$ & $(1 / a)$ & $0-0,3$ & $A_{\text {elo }}$ & $(1 / a)$ & $0-15$ \\
$A_{V P}$ & $(1 / a)$ & $0-25$ & $\max E V P$ & $(-)$ & 0,05 \\
\hline
\end{tabular}


Tabel 4. Parameter waktu pembengkakan (swelling time) Barito Selatan

\begin{tabular}{cccccc}
\hline Parmeter & Satuan & Nilai & Parameter & Satuan & Nilai \\
\hline$A_{0}$ & $(1 / a)$ & $0-0,3$ & $A_{\text {elo }}$ & $(1 / a)$ & $0-5$ \\
$A_{V P}$ & $(1 / a)$ & $0-8$ & $\max E V P$ & $(-)$ & 0,05 \\
\hline
\end{tabular}

Nilai 'a' adalah singkatan dari annum (tahun), Wittke-Gattermann (1998) memperkirakan nilai 'parameter A' setelah simulasi untuk mereproduksi hasil pengukuran in situ dari galeri eksplorasi di terowongan Freudenstein di Jerman, Ini adalah alasan utama bahwa nilai-nilai "A" ditunjukkan menunjukkan tabel lainnya (Tabel 6) digunakan untuk simulasi numerik di Soil Test Facility (Uji Tanah),

Keterangan 'd' adalah singkatan untuk hari, nilai tekanan swelling maksimum harus dimasukkan sebagai nilai positif dalam input model.

Tabel 6. Parameter model konstan oedometer

\begin{tabular}{|c|c|c|c|c|c|c|c|c|}
\hline Parameter & Unit & Value & Parameter & Unit & Value & Parameter & Unit & Value \\
\hline$\varphi^{\prime}$ & $\left(^{\circ}\right)$ & 35 & $A_{0}$ & $(1 / \mathrm{d})$ & $0.1^{6}$ & $E_{p}, E_{t}$ & $(\mathrm{kPa})$ & $4 \mathrm{E}+06$ \\
\hline$c^{\prime}$ & $(\mathrm{kPa})$ & 500 & $A_{e l}$ & $(1 / \mathrm{d})$ & 0 & $K_{q, p}, K_{q, t}$ & $(\%)$ & 0.33 \\
\hline$\psi$ & $\left({ }^{\circ}\right)$ & 0 & $A_{p l}$ & $(1 / \mathrm{d})$ & 0 & $v_{p}, v_{t}$ & $(-)$ & 0.25 \\
\hline$\sigma_{T e n}$ & $(\mathrm{kPa})$ & 0 & $A_{p l} \max$ & $(-)$ & 0.005 & $\sigma_{0, p}, \sigma_{0, t}$ & $(\mathrm{kPa})$ & -750 \\
\hline$G_{23}$ & $(\mathrm{kPa})$ & $1.6 \mathrm{E}+06$ & $\alpha$ & $\left(^{\circ}\right)$ & 0 & Model ID & $(-)$ & 1 \\
\hline
\end{tabular}

\section{C.4 Pembahasan}

Penelitian mengenai perilaku swelling pada saat ini di Indonesia masih kurang banyak diperhatikan, sementara pendekatan untuk analisis selalu menggunakan perilaku plastis. Perilaku (swelling) terjadi akibat adanya air, sehingga perilaku swelling di Indonesia seharusnya menjadi topik pembahasan yang menarik pada kasus pembuatan terwongan dan kasus stabilitas lereng di tambang terbuka. Pada penilitian ini dari hasil analisis XRD terhadap sample dari Kutai Kartanegara dan Barito Selatan ditemukan mineral montmorillonite, kaolinit dan illte. Mineral tersebut menjadikan paramater terjadi perilaku Swelling. Dari hasil penelitian maka parameter yang berpengaruh pada perilaku swelling yaitu Modulus Young, kohesi, sudut gesek dalam, Plactic volumetric strain for plastic strain, Maximum swelling stress - normal dan maximum swelling stress - tangensial.

Penelitian mengenai parameter perilaku swelling yang dilakukan pada penelitian ini, yaitu mensimulasikan terhadap parameter Modulus Young.. Pada penelitian ini didapatkan tiga kondisi Modulus Young sebagai berikut yaitu bertut-turut dengan nilai $\mathrm{E}=118,83 \mathrm{MPa}, 154,58 \mathrm{MPa}$, dan 182,54 MPa untuk mengetahui perilaku displacement di dinding terowongan (lihat Gambar 6).

Hasil analisis terhadap Modulus Young pada Gambar 6, nilai Modulus Young mempengaruhi displacement pada saat berperilaku swelling. Dengan mensimulasikan nilai E maka didapatkan nilai displacement sebesar, untuk nilai $\mathrm{E}=118,83 \mathrm{MPa}$ mengalami displacement sebesar $0.0250 \mathrm{~m}$ pada hari ke $2(0,2178 \mathrm{~m})$ dan hari ke $4(0,2428 \mathrm{~m})$. Pada kondisi tersebut menunjukan bahwa perilaku time swelling parameter for elastic strain dan pada hari ke 4 merupakan kondisi perilaku time swelling parameter for platic strain, pada titik tersebut terjadi perubahan dari kondisi elastis menuju kondisi perilaku plastis. Pada hari ke $4(0,24828 \mathrm{~m})$ sampai dengan hari ke $20(0,2683 \mathrm{~m})$ merupakan kondisi perilaku time swelling parameter. Untuk nilai $\mathrm{E}=145,58 \mathrm{MPa}$ mengalami displacement sebesar $0,0141 \mathrm{~m}$ pada hari ke $2(0.2178 \mathrm{~m})$ dan hari ke $4(0,2319 \mathrm{~m})$. Hal ini juga terjadi pada hari ke $4(0,2319 \mathrm{~m})$ sampai dengan hari ke $20(0,2585 \mathrm{~m})$. Untuk nilai $\mathrm{E}=182,54$ MPa mengalami displacement sebesar 0,1264 m pada hari ke $2(0,0914 \mathrm{~m})$ dan hari ke $4(0,2178$ 
$\mathrm{m})$. demikian seterusnya terjadi pada hari yang sama yaitu hari ke $4(0,2178 \mathrm{~m})$ sampai dengan hari ke $20(0,2481 \mathrm{~m})$ merupakan kondisi time swelling parameter.

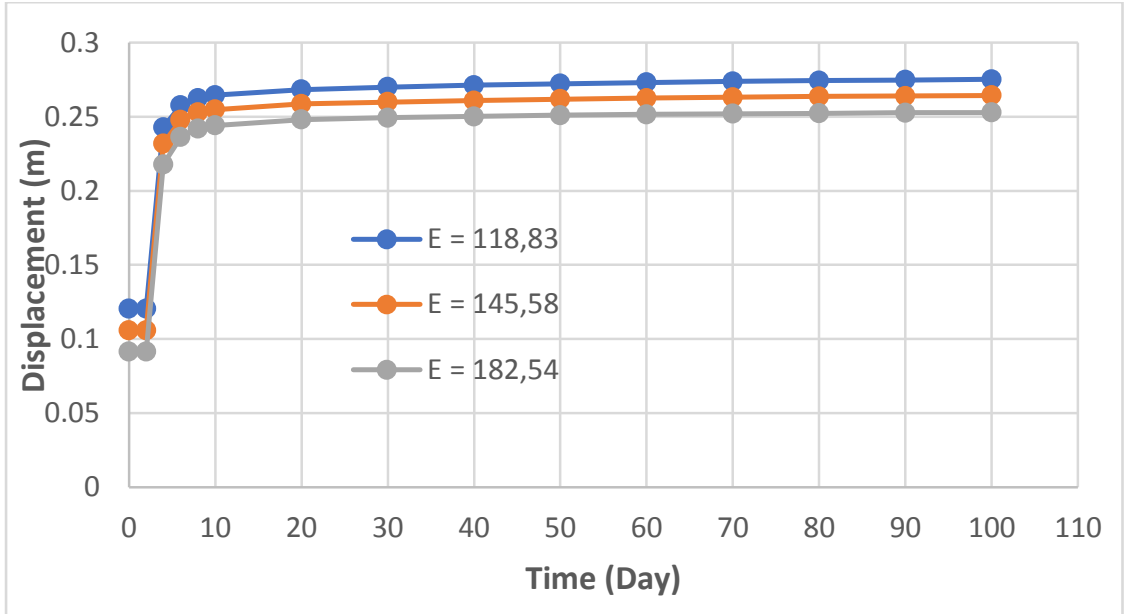

Gambar 6. Perbandingan displacement terhadap nilai Modulus Young pada perilaku swelling

Selain mensimulasikan Modulus Young juga mensimulasikan pengaruh kohesi (c) dengan nilai adalah $0.1 \mathrm{MPa}, 0.2 \mathrm{MPa}$ dan $0.3 \mathrm{MPa}$. Hasil perhitungan dengan parameter kohesi seperti tertera pada Gambar 7. Untuk nilai $\mathrm{c}=0,1 \mathrm{MPa}$ mengalami displacement sebesar $0.1255 \mathrm{~m}$ pada hari ke 2 $(0,1203 \mathrm{~m})$ dan hari ke $4(0,2428 \mathrm{~m})$. Pada kondisi tersebut merupakan kondisi time swelling parameter for elastic strain dan pada hari ke 4 merupakan kondisi time swelling parameter for platic strain, pada titik tersebut terjadi perubahan dari kondisi elastis menuju kondisi perilaku plastis. Pada hari ke $4(0,24828 \mathrm{~m})$ sampai dengan hari ke $20(0,2683 \mathrm{~m})$ merupakan kondisi time swelling parameter. Pada nilai $\mathrm{c}=0,2 \mathrm{MPa}$ dan $\mathrm{c}=0,3 \mathrm{MPa}$ nilai displacement tidak mengalami perubahan, sama dengan kondisi $\mathrm{c}=0,1 \mathrm{MPa}$. Hal ini sesuai dengan teori tegangan - regangan. Pada saat kondisi volumetric strain pada penelitian membuktikan bahwa tidak mengalami perpindahan, dan yang terjadi adalah proses yang dihasilkan oleh mekanisme pergeseran dari hubungan antar butir mineral tersebut (geser micro) saja.

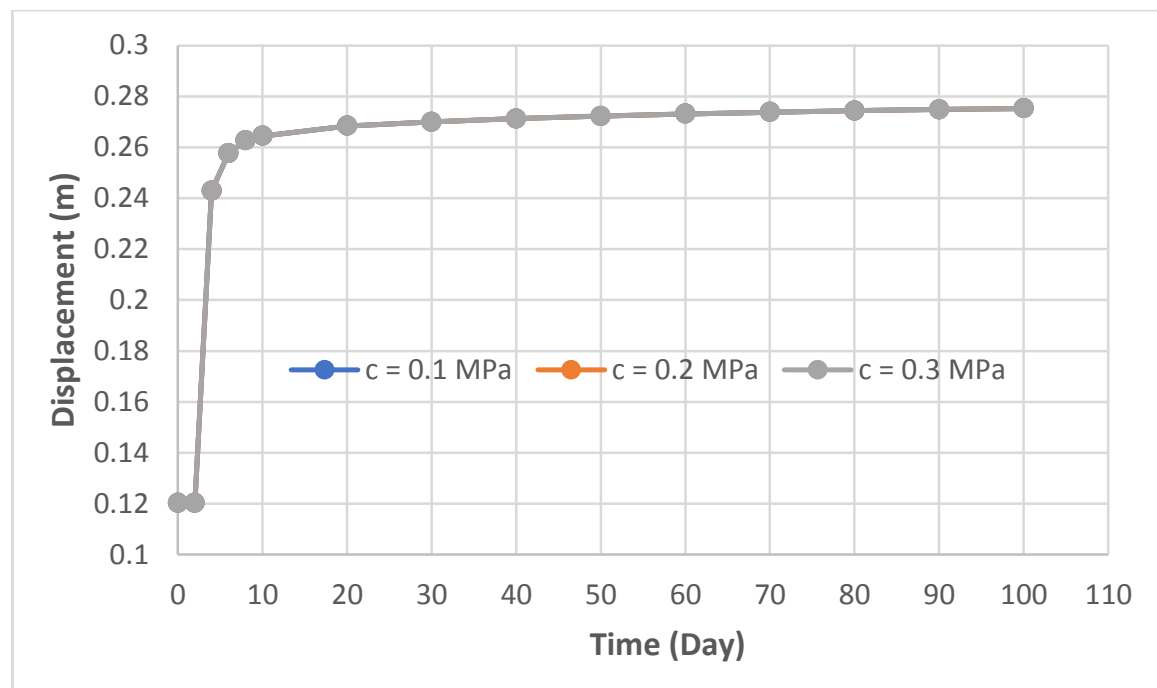

Gambar 7. Perbandingan displacement terhadap nilai kohesi pada perilaku swelling

Pada penelitian ini juga meneliti terhadap pengaruh sudut gesek dalam $(\varphi)$ yaitu nilai $\varphi$ yang disimulasikan $(\varphi)=13,5^{\circ}, 18^{0}$ dan $25^{\circ}$. Hasil perhitungan dapat dilihat pada Gambar 8 . Berdasarkan grafik hasil analisis terhadap nilai sudut gesek dalam pada Gambar 8, dengan 
mensimulasikan sudut gesek dalam $(\varphi)$ maka didapatkan nilai displacement, untuk $(\varphi)=13,5^{0}$ mengalami displacement sebesar $0.1255 \mathrm{~m}$ pada hari ke $2(0,1203 \mathrm{~m})$ dan hari ke $4(0,2428 \mathrm{~m})$.

Pada kondisi tersebut merupakan kondisi time swelling parameter for elastic strain dan pada hari ke 4 merupakan kondisi time swelling parameter for platic strain, pada titik tersebut terjadi perubahan dari kondisi elastis menuju kondisi perilaku plastis. Pada hari ke $4(0,24828 \mathrm{~m})$ sampai dengan hari ke $20(0,2683 \mathrm{~m})$ merupakan kondisi time swelling parameter. Pada nilai sudut gesek dalam $(\varphi) 18^{0}$ dan $25^{\circ}$ nilai displacement tidak mengalami perubahan, sama dengan kondisi kohesi $13,5^{\circ}$. Hal ini sesuai dengan hubungan tegangan - regangan.

Pada penelitian juga meneliti pengaruh parameter plactic volumetric strain for plastic strain $\left(\varepsilon_{p l, \max }\right)$ yaitu $0,05,0,10$ dan 0,15 . Adapun hasil perhitungan pengaruh paramater parameter plactic volumetric strain for plastic strain seperti pada Gambar 9

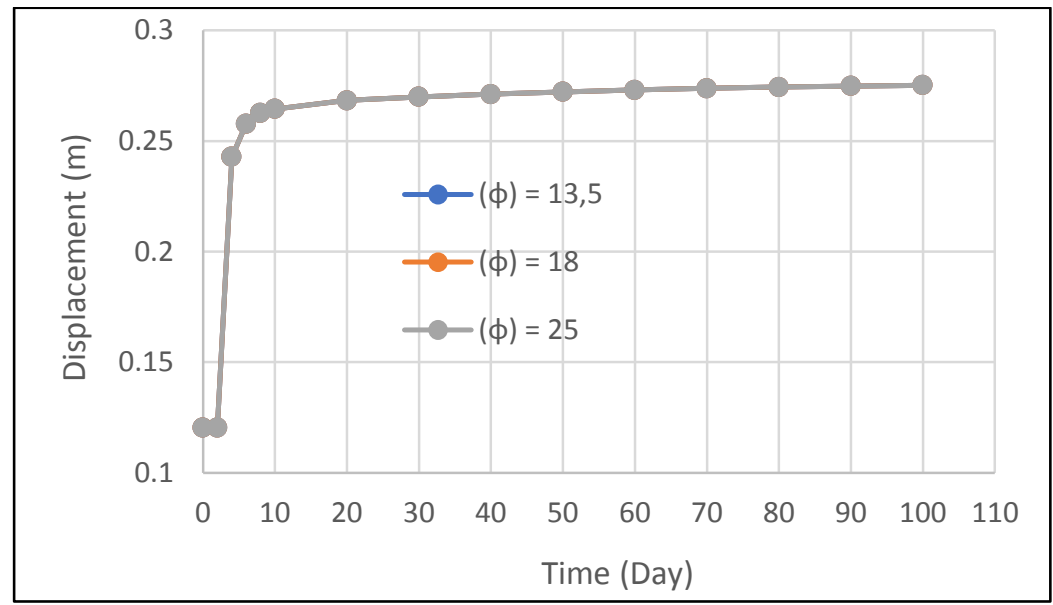

Gambar 8. Perbandingan displacement terhadap nilai sudut gesek dalam $(\varphi)$ pada perilaku swelling

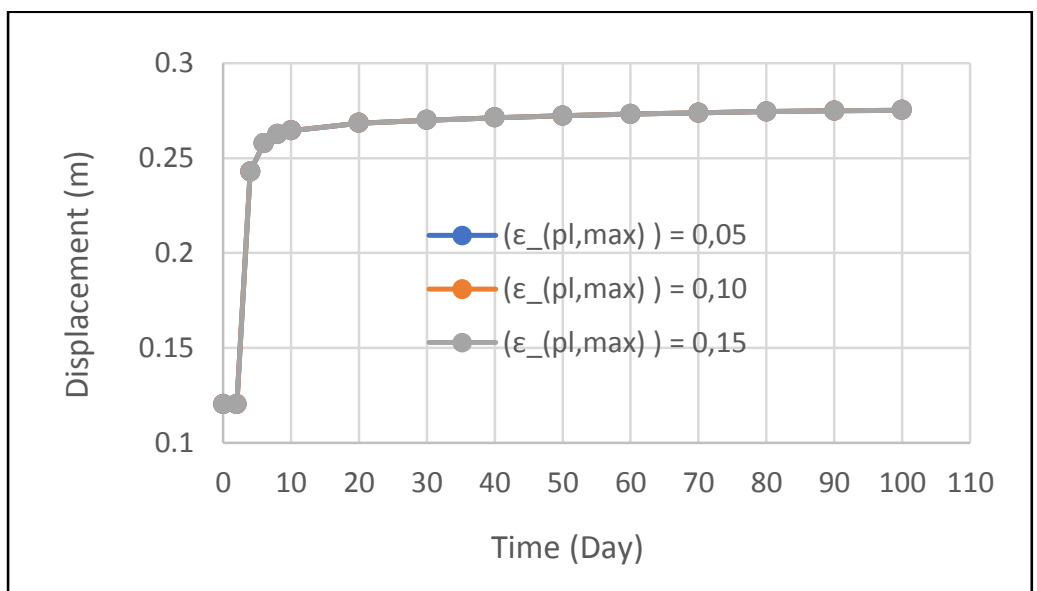

Gambar 9. Perbandingan displacement terhadap plactic volumetric strain for plastic strain $\left(\varepsilon_{p l, m a x}\right)$ pada perilaku swelling

Berdasarkan hasil analisis (Lihat Gambar 9) pengaruh terhadap plactic volumetric strain for plastic strain $\left(\varepsilon_{p l, \text { max }}\right)$ didapatkan nilai displacement, untuk nilai plactic volumetric strain for plastic $\operatorname{strain}\left(\varepsilon_{p l, \text { max }}\right)=0,05$ mengalami displacement sebesar $0.1255 \mathrm{~m}$ pada hari ke $2(0,1203 \mathrm{~m})$ dan hari ke $4(0,2428 \mathrm{~m})$. Sedang pada kondisi plactic volumetric strain for plastic strain $\left(\varepsilon_{p l, \max }\right)$ sebesar 0,10 dan 0,15 MPa nilai displacement tidak mengalami perubahan, sama dengan kondisi 
plactic volumetric strain for plastic strain $\left(\varepsilon_{p l, m a x}\right)$. Pada keadaan tersebut menunjukkan kondisi volumetric strain tidak mengalami perpindaha. Pada masalah swelling volumetric strain ini terjadi juga pada kondisi setelah batas elastis batu lempung terlampaui.

Pada analisis Maximum swelling stress - normal dan maximum swelling stress - tangensial $(\sigma)$ nilai yang disimulasikan yaitu $(0,350) \mathrm{MPa},(0,750) \mathrm{MPa},(1,250) \mathrm{MPa}$ dan $(2,500) \mathrm{MPa}$. Berdasarkan grafik (lihat Gambar 10) hasil analisis terhadap Maximum swelling stress - normal dan maximum swelling stress - tangensial pada Gambar 10, dengan mensimulasikan nilai $(\sigma)$ maka didapatkan nilai displacement sebesar, untuk nilai $(\sigma)=0,350 \mathrm{MPa}$ mengalami displacement sebesar $0.1225 \mathrm{~m}$ pada hari ke $2(0,1203 \mathrm{~m})$ dan hari ke $4(0,2428 \mathrm{~m})$. Pada kondisi tersebut merupakan time swelling parameter for elastic strain dan pada hari ke 4 merupakan kondisi time swelling parameter for platic strain, pada titik tersebut terjadi perubahan dari kondisi elastis menuju kondisi perilaku plastis. Pada hari ke $4(0,24828 \mathrm{~m})$ sampai dengan hari ke $20(0,2684 \mathrm{~m})$ merupakan kondisi time swelling parameter.Adapun ntuk nilai $(\sigma)=0,750 \mathrm{MPa}, 1,250 \mathrm{MPa}$, dan 2,500 MPa mengalami displacement masing sebesar 0,1406 $\mathrm{m}$ pada hari ke $2(0,1203 \mathrm{~m})$ dan hari ke $4(0,2609 \mathrm{~m})$, untuk $1,250 \mathrm{Mpa}$ adalah $0,1511 \mathrm{~m}$ pada hari ke $2(0,1203 \mathrm{~m})$ dan hari ke 4 $(0,2714 \mathrm{~m})$, untuk 2,500 Mpa sebesar 0,1627 m pada hari ke $2(0,1203 \mathrm{~m})$ dan hari ke $4(0,2830$ m).Pada kondisi tersebut merupakan time swelling paramter for elastic strain dan pada hari ke 4 merupakan kondisi time swelling parameter for platic strain, pada titik tersebut terjadi perubahan dari kondisi elastis menuju kondisi perilaku plastis, masing-masing sebesar Pada hari ke $4(0,2609$ $\mathrm{m})$ sampai dengan hari ke $20(0,2897 \mathrm{~m})$, hari ke $4(0,2714 \mathrm{~m})$ sampai dengan hari ke $20(0,3028$ $\mathrm{m})$, ke $4(0,2830 \mathrm{~m})$ sampai dengan hari ke $20(0,3192 \mathrm{~m})$ merupakan kondisi time swelling parameter.

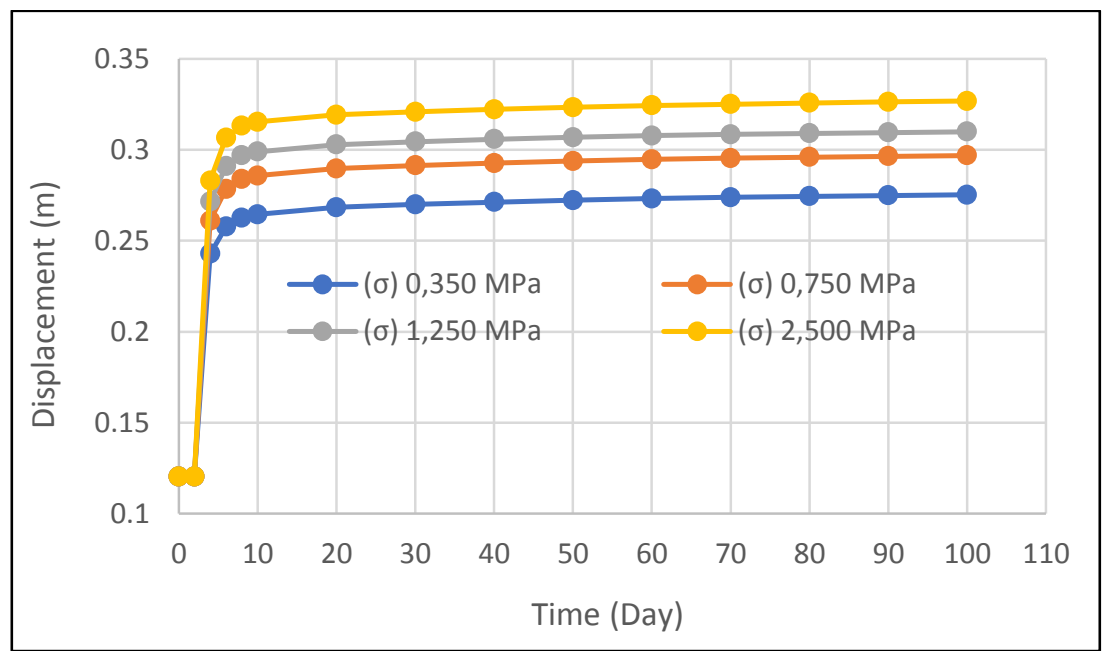

Gambar 10 Perbandingan displacement terhadap Maximum swelling stress - normal dan maximum swelling stress - tangensial pada perilaku swelling

\section{KESIMPULAN}

Pada perilaku swelling semakin besar nilai modulus young maka nilai displacementnya semakin kecil. Besar atau kecil nilai kohesi, sudut gesek dalam dan tensile strength pada perilaku swelling tidak mempengaruhi displacement hal ini dikarenakan pengaruh volumetric strain bukan gesekan (shear).

\section{UCAPAN TERIMAKASIH}


Ucapan terimakasih diberikan kepada Bapak Dr. Ir. Barlian Dwinagara, MT. yang telah membantu kepada penulis memberikan contoh batulempung dari daerah Kutai Kertanegara dan Barito Selatan untuk dijadikan inspirasi terhadap penelitian Swelling ini.

\section{DAFTAR PUSTAKA}

Anagnostou, G., 1993. A model for swelling rock in tunnelling. Swiss federal institute of technology, Zurich, Switzerland, Journal of Rock Mechanics and Rock Engineering, pp. 307-331.

Dhanti, P.N.H., Prabawa, A.D., Laitupa, K., 2017. Studi Kandungan Mineral Clay Pada Pembawa Lapisan Batubara Untuk Memprediksi Adanya Potensi Swelling Pada Lantai Tambang Batubara Bawah Tanah..Padang; Proceeding Seminar Nasional Geomekanika IV Padang 26 Oktober 2017.hal 23-32.

Grob, H. 1976. Swelling and Heave in Swiss Tunnels, Bull. Int. Assoc. Engng. Geol. 13, 55-60.

Huder, J. \& Amberg, G. (1970). Quellung in Mergel, Opalinuston und Anhydrit. Schweizerische Bauzeitung 43, 975-980

Pusch, R. 2012. Environmental Soil Properties and Behaviour, Swelling Clays, chapter 4. CRC Press, Taylor \& Francis Group, LLC: pp.133-161.

S. Supriatna, Sukardi, dan E. Rustandi, Tahun 1995: Peta Geologi Lembar Samarinda, Kalimantan, Skala 1:250.000. Pusat Penelitian dan Pengembangan Geologi Bandung.

Sikumbang, N., dan Heryanto, R., 1994. Peta Geologi Lembar Banjarmasin, Skala 1:250.000. Pusat Penelitian dan Pengembangan Geologi Bandung.

White, Joe L.,1956.Reaction of Molten Salt With Layer Lattice Silicates: in Clay and Clay Minerals, Acad.Sci-Nat.Res.Council.pub 456, p. 133-146.

Wittke-Gattermann, P., 1998. Verfahren zur Berechnung von Tunnels in quellfähigem Gebirge und Kalibrierung an einem Versuchsbauwerk. Geotechnik in Forschung und Praxis, WBI-PRINT 1, Verlag Glückauf, Essen 
PROSIDING TPT XXVIII PERHAPI 2019 